\title{
Determinant of Milk Market Outlet Choices:The Case of Kofele District, West Arsi Zone, Oromia, Ethiopia
}

\author{
Mohammed Ayyano $^{1} \quad$ Mustefa Bati (Assistant Professor) $^{2} \quad$ Tura Kaso(Assistant Professor) $^{1}$ \\ 1.Department of Agribusiness and Value Chain Management, Ambo University, Ambo, Ethiopia \\ 2.Department of Agricultural Economics, Mattu University, Ethiopia
}

\begin{abstract}
The study was aimed at Determinant of milk market outlet choices Kofale district, West Arsi Zone, Oromia Ethiopia with the specific objectives of identifying factors affecting milk market participation decision and the level of participation of milk. Data for this study were collected from both primary and secondary sources. Primary data were collected from 142 farmers, 59 traders, 2 cooperatives and 23 consumers. A primary data was collected from the milk value chain actors using semi-structured questionnaires', key informants, and focus group discussion guide checklist. to analyze the determinants of the producers market participation decision and level of participation double hurdle model was applied. Multivariate probit model used to identify the determinants of market outlets choice decisions. The multivariate probit model results indicated that sex, dairy farming experience, dairy cooperative membership, number of milking cow owned frequency of extension contact, off/non-farm income and access to transportation facility of farm households were significantly influenced milk producers' choice of market outlets.
\end{abstract}

Keywords: Milk, Market outlet, Multivariate probit

DOI: $10.7176 / \mathrm{JBAH} / 10-7-06$

Publication date: April $30^{\text {th }} 2020$

\section{INTRODUCTION}

Ethiopia holds large potential for dairy development particularly Ethiopian highlands possess a high potential for with diverse topographic and climatic conditions favorable for dairying (Gezu and Zelalem, 2018). The traditional smallholder milk production system produces 97 percent of the total national milk production and 75 percent of the commercial milk production. This sector is largely dependent on indigenous breeds of low-productivity native zebu cattle, which produce about 400-680 kg of milk /cow per lactation period (Zelalem et al., 2011). As dairying play a significant role in the lives of the urban and peri-urban poor households, promotion of the dairy sector in Ethiopia can, therefore, contribute significantly to poverty alleviation as well as, availability of food and income generation (Yitaye et al., 2007). In addition, a very small number of crossbred animals are milked to provide the family with fresh milk butter and cheese (Getachew, 2015). Surpluses are sold, usually by women, who use the regular cash income to buy household necessities or to save for festival times (Mugerewa et al., 2009).

Despite a large number of livestock and dairy production in Ethiopia, there are a number of fundamental constraints underly these outcomes. Berhanu et al.(2013) study on factors affecting milk market outlet choices in Wolaita zone, Ethiopia, include poor marketing infrastructure, limited supply of different inputs (feed, breed, stock, and water), poor or non-existent of extension service, lack of marketing support service, high diseases prevalence, lack of market information, traditional technologies and limited credit services affect the livestock marketing conditions.

The application of value chain analysis in agriculture is a solution to market failure and non-competitive setting of small-scale agricultural production. Value chain and innovations are also interlinked. Improvement in productivity and competitiveness of the value chain is the litmus test for value chain innovation (Anandajayasekeram and Gebremedhin, 2009).

Accordingly, Producers' knowledge of alternative sales outlets and of prices they offer was, generally, enhance their bargaining position and improve their chances of getting the highest prices for their products. Producers were also have the flexibility to shift between outlets to obtain the best prices. The factors affecting the selection of milk sales outlets are the distance from the market, price, dairy extension service, market information (Berhanu et al., 2013). About 48\% of urban producers consider proximity and better price while selecting sales outlets. The majority of the urban producers $(71.2 \%)$ sell directly to consumers. Contrary to this, peri-urban producers $(62 \%)$ mainly supply to processors. The major actors in the milk marketing value chain are producers, vendors, processors, wholesalers, retailers, catering enterprises and consumers. Recently, vendors have become collectors of raw milk from farmers and deliver to processors at factory gates (Azage et al., 2013).

In Oromia regional state, agriculture remains to be the dominant economic sector. In 2018, the region has a total of $24,432,974$ cattle and $40.9 \%(9,995,854)$ are milking cows, total milk produced in a region is $1,473,195,406$ Lts. It has the highest share (44.42\%) milk production from the rest of eight region and Average Daily milk produced is 1.475 which is greater than the national level of the country (CSA, 2018). Similarly, West Arsi Zone is well known in milk production. Wytze et al. (2013) reviewed west Arsi zone (kofele, Dodola, and 
Arsi Nagele) are the most milk shed district.

Kofele district, where the study focused, is endowed with suitable for livestock and dairy production. Most farmers in the area produce milk for home consumption, in the form of raw milk and ergo. Still, most of the milk sold to the market, after deducting the needed for home consumption and buying for grass or feed (cost of feeding). As such, milk plays an important role in generating cash income in the area. According to the KDLFDO (2018), the annual production was 26.9 million liters of milk at an average of 2.8 liters/ cow from 26,252 current milking cow.

However, determinant of milk market outlets choices have not yet been studied and analyzed for the target study area, where great potential of milk production exists. Therefore, this study aims at analysis of milk outlets choices determinant in Kofele district.

\section{METHODOLOGY}

This study was undertaken in kofele district of Oromia regional state of southern Ethiopia, which has been potential in the production of milk. Kofele is one of the districts in the Oromia Region of Ethiopia. The study area has good climatic conditions and this is an opportunity for rearing dairy cows. The agro ecology of the area is tepid to high land (91\%) and Midland (9\%). The elevation of the area ranges between 1040 - 3574 masl. The mean annual temperature ranges from a minimum of $15^{\circ} \mathrm{C}$ to an average annual maximum of $25^{\circ} \mathrm{C}$ and the annual rainfall varies between 800-1200mm and rainfall starts in June and ends in October (KDANRM, 2019).

Kofele district has various land use types that could be classified into arable land, grazing land and forestland. The district has a total area of 32835 ha of which 9534.57 ha arable land, 7721 ha grazing land, and 4405.5 ha forestland (KDANRM, 2019).

The district has 38 rural Kebele and 3 towns and all of them participate in milk production. The 2007 national census reported a total population of the district to be 105,614 people, of whom 52,888 were male and 52,726 were female. It is the area where livestock farming is an important component of the farming system and one of the high actual productivity areas for milk production in the district. The district also endowed with a significant number of domestic animals; 97,560 cattle, out of which 89,240 indigenes cattle 8320 are crossbred, 39,206 sheep, 2107 goats, 229 equines, 75,450 poultry, and 5786 honeybee colonies are found in the district (KDLFDO, 2019). Milk production in the district was 74,986 liter of milk produced per day or 2.25 million litter of milk per month or 26.9 million liters of milk per annual from 26,252 milking cow comprising of 23,913 local and 2339 cross milking cow.

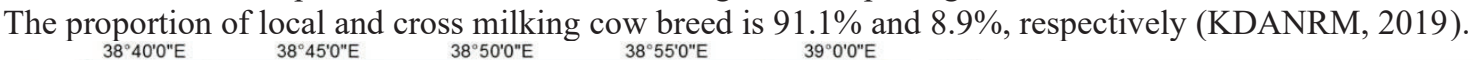

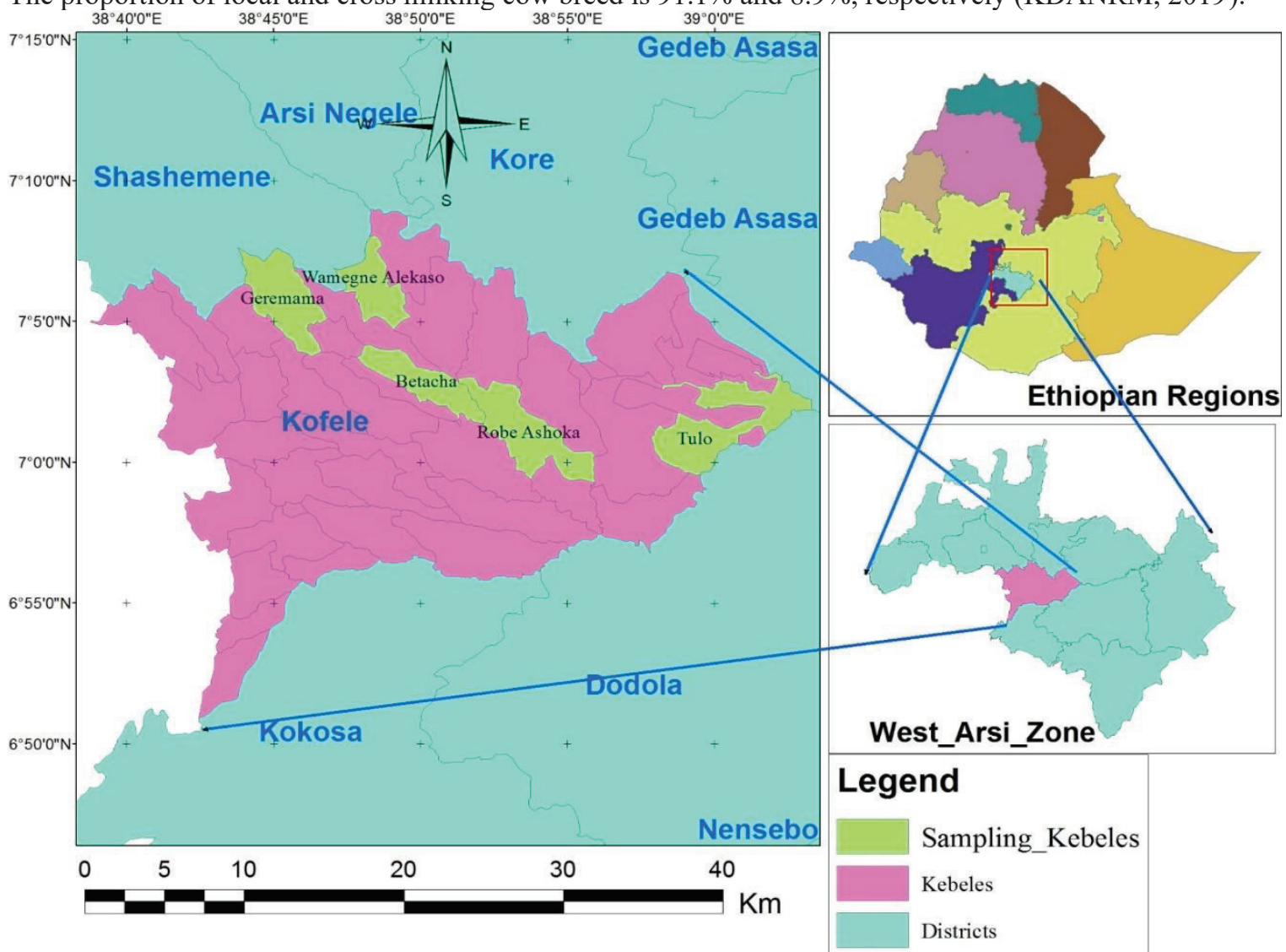

Figure 1: Geographical location of the study area. 


\section{Type, Source and Method of Data Collection}

Both primary and secondary as well as quantitative and qualitative data were used for this study. Primary data was obtained from milk producers, rural milk collectors, Dairy cooperatives, café/hotel, and consumers. Secondary data was obtained from different literatures such as books, journals, research reports, different unpublished reports and documents, Central Statistical Authority (CSA) and internet websites.

A primary data was collected from the milk value chain actors using semi-structured questionnaires', key informants, and focus group discussion guide checklist. A total of five focus group discussions involving 8-10 members in each group were held in selected kebeles to collect the relevant data for the study. Before conducting the final survey, Rapid Market Appraisal (RMA) was undertaken to have some picture on the marketing system of milk. Five of enumerators were recruited and trained for data collection.

\section{Sampling Procedure and Sample Size Determination}

Two-stage sampling procedure was used to draw a representative sample of milk value chain actors from the target population in the study district. In the first stage, stratified sampling techinique was implemented in order to come up with homogenous kebeles. 41 (Forty one) kebeles of the study area were classified into two: that is high 14 (fourteen) and low 27 (twenty seven) milk producer kebeles based on their existing milk production level and market access via the list provided by District Offices of Livestock and Lishery Development. Then, 5 (five) sample kebeles of the district was selected randomly out of 14 (fourteen) high milk producer kebeles. In the second stage, a total of 142 households were selected randomly from these 5 selected kebeles, using probability proportionate to size of milk producer households in the kebeles. The sample size was determined based on the formula given by Yamane (1967) at 92\% confidence level and error term $8 \%$.

$\mathrm{n}=\frac{\mathrm{N}}{1+\mathrm{Ne}^{2}} \quad$ Where $\mathrm{n}=$ is sample size

$\mathrm{N}=$ is number of milk producer households' in the selected kebeles which is 1558

$\mathrm{e}=$ is error term $8 \%(0.08)$

The total sample size: $\mathrm{n}=\frac{1558}{1+1558 *(0.08)^{2}}=142.01 \sim 142$

Therefore, a total of 142 milk producing farm households was taken as samples to conduct this study.

Table 1: Sample of selected district's kebeles milk producing households

\begin{tabular}{lccccc}
\hline & \multicolumn{3}{l}{ Milk producer households } & & \\
Name of the $\boldsymbol{k e b e l e}$ & Male & Female & Total & Proportionality & Sample \\
\hline Robe Ashoka & 304 & 34 & 338 & 0.22 & 31 \\
W/Halkaso & 257 & 20 & 277 & 0.17 & 25 \\
Tulo & 327 & 24 & 351 & 0.23 & 32 \\
Bitacha & 284 & 19 & 303 & 0.20 & 28 \\
Garmama & 263 & 26 & 289 & 0.18 & $\mathbf{1 4 2}$ \\
\hline Total & $\mathbf{1 4 3 5}$ & $\mathbf{1 2 3}$ & $\mathbf{1 5 5 8}$ & $\mathbf{1 . 0 0}$ & \\
\hline
\end{tabular}

Source: own computation from KDALFO 2019

In addition, to producers the value chain actors like, dairy cooperative, collectors, retailer, and cafes/hotel were selected on the basis of their size and availability. Accordingly, 2 dairy cooperative, 5 collector, 23 cafes/hotel, and 12 retailer were selected census based on the list of licensed traders information obtained from kofele district office of Trade and Industry. However, from Shashamane city cafes/hotel and retailer were selected by follow footstep of product flow in the channels. Accordingly, 11 cafes/hotel owner and 8 retailers were selected by taking information from cooperative and collector interview of the kofele district where they sell. Furthermore, 14 consumers were interviewed from kofele district and 9 consumer from Shashamane city, which were selected a purposively to obtain information related to consumers

\section{Method of Data Analysis}

Two types of data analysis, namely descriptive statistics and econometric models was used to analyze the data collected from the households. Descriptive method of data analysis includes the use of percentages, means and standard deviations. Econometric model was used to analyze determinant of smallholder milk producer households milk market outlet choice using multivariate probit model.

\section{Modeling choice of channel}

The choice of marketing outlet was based on producers' socio-economic characteristics and relevant factors influencing the choice imbedded in each channel. The base for market channel choice is the theory of rational choice which assumes that farmers are rational and would rank alternative marketing outlet for utility maximization. 
The producers' market outlet choice can be conceptualized using a Random Utility Model. The model is particularly applicable for modeling discrete choice decisions such as market outlet choices. It is an indirect utility function where an individual with specific characteristics associates an average utility level with each alternative outlet in a choice set (Tarekegn et al., 2017).

Multinomial models are applicable if marketing channels are mutually exclusive and farmers can choose one best channel as their market outlet (Zegeyesh, 2016). However, in the study area, smallholder milk producers face different choices of market outlets like: dairy cooperative, collector, retailer and consumers. Thus, in this study since milk is one of the income-generating commodity that enables producers to choose more than one outlets that are not mutually exclusive to get better price. Considering the possibility of simultaneous choices of outlets and the potential correlations among these market outlet choice decisions multivariate probit model (mvprobit) was appropriate and applied to capture household variation in the choice of market outlets and to estimate several correlated binary outcomes jointly.

Multivariate probit approach simultaneously models the influence of the set of independent variables on choice of market channels, while allowing for the potential correlations between unobserved disturbances, as well as the relationships between the choices of different market channels (Belderbos et al., 2004).

The observed outcome of market channel choice can be modeled following random utility formulation. Consider the $\mathrm{i}^{\text {th }}$ farm household $(\mathrm{i}=1,2 \ldots \mathrm{N})$ facing a decision problem on whether or not to choose available market. Let $\mathrm{U}_{0}$ represent the benefits to the farmer who chooses dairy cooperative, and let $\mathrm{U}_{\mathrm{K}}$ is represent the benefit of farmer to choose the $\mathrm{K}^{\text {th }}$ market choice: where $\mathrm{K}$ denotes choice of dairy cooperative $\left(\mathrm{Y}_{1}\right)$, collectors $\left(\mathrm{Y}_{2}\right)$, retailers $\left(\mathrm{Y}_{3}\right)$, and individual consumer $\left(\mathrm{Y}_{4}\right)$. The farmer decides to choice the $\mathrm{K}^{\text {th }}$ market choice if $\mathrm{Y}_{\mathrm{ik}}^{*}=\mathrm{U}_{\mathrm{k}}^{*}$ $\mathrm{U}_{0}>0$. The net benefit $\left(\mathrm{Y}_{\mathrm{ik}}^{*}\right)$ that the farmer derives from choosing a market choice is a latent variable determined by observed explanatory variable $X_{i}$ and the error term $\left(\varepsilon_{i}\right)$.

$\mathrm{Y}_{\mathrm{ik}}^{*}=\mathrm{X}_{\mathrm{i}} \beta_{\mathrm{k}}+\varepsilon_{\mathrm{i}} \quad \mathrm{k}=\mathrm{Y}_{1}, \mathrm{Y}_{2}, \mathrm{Y}_{3}$ and $\mathrm{Y}_{4}$

Using the indicator function, the unobserved preferences in equation (1) translates into the observed binary outcome equation for each choice as follows:

$\mathrm{Y}_{\mathrm{ik}}=\left\{\begin{array}{c}1, \text { if } \mathrm{Y}_{\mathrm{ik}}^{*}>0, \quad \mathrm{k}=\mathrm{Y}_{1}, \mathrm{Y}_{2}, \mathrm{Y}_{3} \text { and } \mathrm{Y}_{4} \\ 0, \text { otherwise }\end{array}\right.$

In multivariate model, where the choice of several milk market choice is possible, the error terms jointly follow a multivariate normal distribution (MVN) with zero conditional mean and variance normalized to unity for identification of the parameters where $\mu_{\mathrm{y} 1}, \mu_{\mathrm{y} 2}, \mu_{\mathrm{y} 3}, \mu_{\mathrm{y} 4} \mathrm{MVN} \sim(0, \Omega)$ and the symmetric covariance matrix $\Omega$ is given by:-

$\left[\begin{array}{lccc}1 & \rho_{\mathrm{y} 1 \mathrm{y} 2} & \rho_{\mathrm{y} 1 \mathrm{y} 3} & \rho_{\mathrm{y} 1 \mathrm{y} 4} \\ \rho_{\mathrm{y} 2 \mathrm{y} 1} & 1 & \rho_{\mathrm{y} 2 \mathrm{y} 3} & \rho_{\mathrm{y} 2 \mathrm{y} 4} \\ \rho_{\mathrm{y} 3 \mathrm{y} 1} & \rho_{\mathrm{y} 3 \mathrm{y} 2} & 1 & \rho_{\mathrm{y} 3 \mathrm{y} 4} \\ \rho_{\mathrm{y} 4 \mathrm{y} 1} & \rho_{\mathrm{y} 4 \mathrm{y} 2} & \rho_{\mathrm{y} 4 \mathrm{y} 3} & 1\end{array}\right]$

Of particular interest are off-diagonal elements in the covariance matrix, which represent the unobserved correlation between the stochastic components of the different type of choice. This assumption means that equation (21) generates a MVP model that jointly represents decision $\mu$ to choice particular market choice. This specification with non-zero off-diagonal elements allows for correlation across error terms of several latent equations, which represents unobserved characteristics that affect the choice of alternative outlets (Tarekegn et al., 2017).

Following the form used by Cappellari and Jenkins (2003), the log-likelihood function associated with a sample outcome is then given by:

$$
\ln L=\sum_{\mathrm{i}=0}^{\mathrm{N}} \varpi_{\mathrm{i}} \mathrm{t} \Phi_{\mathrm{i}}\left(\mu_{1}, \Omega\right)
$$

Where $\varpi$ is an optional weight for observation $i$, and $\Phi$ is the multivariate standard normal distribution with arguments and $\Omega$, where $\mu_{\mathrm{i}}$ can be denoted as;-

$$
\begin{aligned}
& \mu_{\mathrm{i}}=\mathrm{k}_{\mathrm{i} 1} \beta_{1} \mathrm{X}_{\mathrm{i} 1}, \mathrm{k}_{\mathrm{i} 2} \beta_{2} \mathrm{X}_{\mathrm{i} 2}, \mathrm{k}_{\mathrm{i} 3} \beta_{3} \mathrm{X}_{\mathrm{i} 3,} \quad \text { while } \Omega_{\mathrm{ik}}=1 \text { for } \mathrm{j}=\mathrm{k} \\
& \Omega_{\mathrm{jk}}=\Omega_{\mathrm{kj}}=\mathrm{k}_{\mathrm{ij}} \mathrm{k}_{\mathrm{ik}} \rho_{\mathrm{jk}} \text { for } \mathrm{j} \neq \mathrm{k}, \mathrm{k}=1,2,3 \ldots \text { with } \mathrm{k}_{\mathrm{ik}}=2 \mathrm{k}_{\mathrm{ik}}-1
\end{aligned}
$$




\section{Dependent variables}

Market outlet choice: Market outlet choices was dummy variable and it took 1 if producers' choice was $i^{\text {th }}$ outlet choice and zero otherwise. Each sampled household would use one or more marketing outlet. A sampled household would be choosing one or more of the milk market outlet if and only if the utility expected is higher than otherwise. Table 2: Variables affect market outlet choice

\begin{tabular}{|c|c|c|c|c|}
\hline No & Variable & $\begin{array}{l}\text { Variables } \\
\text { symbols }\end{array}$ & Measurement & $\begin{array}{l}\text { outlet } \\
\text { choice }\end{array}$ \\
\hline 1 & Sex of the household head & SEXH & Dummy: $1=$ if male $; 0=$ otherwise & \pm \\
\hline & Educational level of household & EDLH & $\begin{array}{l}\text { Category; } 0 \text { if do not follow formal school, } \\
\text { 1primary, } 2 \text { secondary, 3teriary and above. }\end{array}$ & \pm \\
\hline 3 & Dairying farm experience & EXMP & Continuous; in a year & \pm \\
\hline 4 & Family size & FAMSH & Continuous; in number & \pm \\
\hline 5 & Membership to dairy cooperative & MDCOP & Dummy: $1=$ if male $; 0=$ otherwise & \pm \\
\hline 6 & Distance from the nearest market & DNM & Continuous; kilometer & \pm \\
\hline 7 & Number of milking cows owned & $\mathrm{NMCO}$ & Continuous;No. & \pm \\
\hline 8 & $\begin{array}{l}\text { Milk allocated for home } \\
\text { consumption }\end{array}$ & MAHCON & Continuous;Liters & \pm \\
\hline 9 & Land size allocated for grazing & LAND & Continuous; in hectare & \pm \\
\hline 10 & Off/non-farming income & OFFARM & Continuous; measured in Birr. & \pm \\
\hline 11 & Frequency of extension contact & FEC & Continuous; number of a day contact & \pm \\
\hline 12 & Transport ownership facility & TOF & Dummy: $1=$ uses transp & \pm \\
\hline
\end{tabular}

Source: Own hypothesis based on review of literature (2019)

\section{RESULTS AND DISCUSSIONS}

Milk Marketing Outlets

The sampled households were asked if they choose different milk market outlets to maximize the profit from their outlet choice decision. Accordingly, they reported that different milk market outlets were used to sale their milk produced. These milk market outlets include cooperatives, collectors, retailers, and consumers. These outlets are mostly chosen in combination with one another. Table 3 shows the different milk market outlets used by the milk producer when selling their milk. One of the most commonly used market outlets by producers is the retailer outlet which was chosen by about $48.59 \%$ respondents with mean supply of 3.93 liters/day. However, is statically insignificant between household who select retailer outlet and do not choice. About 42.25\%, 40.68\% of respondents sold to cooperative and collector with mean supply of 3.86 liter/day and 3.4 liter/day, respectively and both of them were statically significant difference between household who choice cooperative and collector and who do not choice them at 5\% significant level. As consumers are also a common milk marketing outlet in the study area, around $38.03 \%$ of sample households sold to the collectors with mean supply of 3.42 liters and it is statistically significant at 5\% level.

Table 3: Description of milk market outlets

\begin{tabular}{lllll}
\hline & cooperative & Collectors & Retailers & consumers \\
\cline { 2 - 5 } Decision & percent & percent & percent & Percent \\
\hline Yes & $42.25 \%$ & $40.68 \%$ & $48.59 \%$ & $38.03 \%$ \\
No & $57.75 \%$ & $59.32 \%$ & $51.41 \%$ & $61.97 \%$ \\
Chi-square & $11.1664 * *$ & $7.0900^{* *}$ & 3.6271 & $10.1016^{* *}$ \\
Supply to each outlet & Mean & Mean & Mean & Mean \\
& 3.86 & 3.4 & 3.93 & 3.42 \\
\hline
\end{tabular}

Note: $* *$ is statistically significant at $5 \%$ significance level

Source: Computed based on survey data, 2019 


\section{Determinant of Milk Producers' Market Outlet Choice}

The expected multivariate interdependence of choice of the specific market outlet of collectors, dairy cooperatives, retailer, and consumers were computed by employing the multivariate probit model (Table 4).

The model fits the data reasonably well. The Wald chi-square statistic $(\chi 2(56)=183.34, \rho=0.000))$ that helps to test for the overall significance of the model is significant at $1 \%$ probability level. This result infers that of coefficients are jointly significant and the explanatory power of the factors included in the model is satisfactory. The likelihood ratio test of the null hypothesis of independence between the market channel decision $(\rho 21=\rho 31$ $=\rho 41=\rho 32=\rho 42=\rho 43=0)$ is significant at $1 \%$. Therefore, the null hypothesis that the $\rho$ (Rho) values are jointly equal to zero is rejected, indicating the goodness-of-fit of the model (Table 18).

Separately considered, the $\rho$ values $\left(\rho_{\mathrm{ij}}\right)$ indicate the degree of correlation between each pair of dependent variables. The $\rho_{21}$ (correlation between the choice of collector and cooperative outlet), $\rho_{31}$ (correlation between the choice of retailers and cooperative outlet) is negative and statistically significant at $1 \%$ significance level; and $\rho_{42}$ (correlation between the choice of consumer and collector outlet) are positive and statistically significant at $5 \%$ level. This result indicates that farmers selling their milk production to the cooperative outlets are less likely to deliver to retailers and collectors outlets. Similarly, those farmers marketing milk to the consumer outlet are less likely to deliver to collectors market outlets (Table 4).

The simulation results also indicate that the marginal success probability for each equation (outlet choice decision) is reported below. The likelihood of choosing consumer outlet is relatively low (43\%) as compared to the probability of choosing cooperative outlet (45\%), collector outlet (44\%) and retailer outlet (45\%). This is an indicator that retailer is the most likely chosen market outlet by farmers and the low capacity of consumer outlet to purchase more milk product at a time and the remoteness of producers from urban consumers outlet. The joint probabilities of success or failure of choosing four outlets suggests that the likelihood of households jointly choose the four outlets is low. The likelihood of households jointly choose the four outlets was $3 \%$, which is relatively lower to their failure jointly choose them (8\%). The result in Table 4, indicated that out of explanatory variables used in the multivariate probit model, sex of household, dairy farming experience, land size allocated for grazing and membership to a dairy cooperative. Moreover, the number of milking cows owned, and Off/non-farm income household, Frequency of extension contact, and Transport ownership facilities were found to significantly affect the market outlet choice behavior of milk producers.

Sex of household (SEX): Sex (male) was negatively and significantly associated with the use of collector outlet at $5 \%$ significance level while household sex (male) was positively and significantly associated with the use of retailer outlet at $10 \%$ significance level. It is also interesting to note that male head producers are less likely to deliver milk to the collector outlet than female head household. Females as head of the household are confronted with the household roles and therefore they do not select other market outlets because it requires moving out of the homestead to the point of buyers. This is a line with kadigi (2013) found that positive and significant relationship between being a female dairy farmer and the likelihood to choose vendors/local collector as milk market outlet mean that, the female-headed dairy household would increase the probability for marketing milk to milk vendors.

Dairy farming experience has a significant and positive relationship with the likelihood of choosing dairy cooperative and consumers' market outlet at 10\% and 5\% significant level, respectively. This result shows that an increase in farmers' experience increases the likelihood of selling milk to choosing dairy cooperative and consumer market outlets. The possible explanation might be that older producers prefer selling for cooperative and consumers who buy on a cash basis at the farm gate than other outlets. Similar to this result, Berhanu et al. (2013) found that a number of years a household has been in dairy farming positively and significantly affected accessing cooperative milk market outlet as compared with accessing individual consumers outlet. 
Table 4: Multivariate probit estimation results for market outlet choices

\begin{tabular}{|c|c|c|c|c|c|c|c|c|}
\hline \multirow[t]{2}{*}{ Varaible } & \multicolumn{2}{|c|}{ Cooperative } & \multicolumn{2}{|c|}{ Collector } & \multicolumn{2}{|l|}{ Retailers } & \multicolumn{2}{|c|}{ Consumers } \\
\hline & Coef. & RSE & Coef. & RSE & Coef. & RSE & Coef. & RSE \\
\hline cons & $-2.19 * * *$ & 0.78 & 0.55 & 0.69 & $-2.02 * * *$ & 0.73 & $-1.80 * *$ & 0.77 \\
\hline$\overline{\mathrm{SEX}}$ & 0.13 & 0.34 & $-0.48 * *$ & 0.31 & $0.56^{*}$ & 0.31 & 0.17 & 0.35 \\
\hline \multicolumn{9}{|l|}{ EDUC } \\
\hline Primary & -0.17 & 0.30 & 0.07 & 0.28 & 0.14 & 0.30 & 0.19 & 0.31 \\
\hline Secondary & 0.25 & 0.34 & 0.46 & 0.33 & 0.19 & 0.34 & 0.08 & 0.38 \\
\hline Tertiary & 0.10 & 0.48 & 0.15 & 0.47 & 0.26 & 0.46 & 0.61 & 0.50 \\
\hline EXPER & $0.09 *$ & 0.05 & 0.01 & 0.04 & -0.03 & 0.04 & $0.11 * *$ & 0.04 \\
\hline FAMSIZE & -0.05 & 0.06 & 0.00 & 0.06 & 0.00 & 0.06 & 0.04 & 0.07 \\
\hline GLHS & $0.31 *$ & 0.16 & 0.11 & 0.15 & $0.27 *$ & 0.16 & -0.17 & 0.15 \\
\hline MDCOOP & $0.93 * * *$ & 0.27 & -0.05 & 0.26 & 0.18 & 0.27 & -0.31 & 0.26 \\
\hline DNMP & -0.18 & 0.14 & 0.04 & 0.13 & -0.14 & 0.14 & 0.00 & 0.13 \\
\hline NMCO & -0.03 & 0.08 & $0.30 * * *$ & 0.10 & -0.03 & 0.09 & 0.18 & 0.10 \\
\hline OFFARM $\left(* 10^{-4}\right)$ & 0.12 & 0.10 & -0.13 & 0.09 & $0.17 *$ & 0.10 & -0.01 & 0.10 \\
\hline FEC & 0.05 & 0.22 & $-0.54 * *$ & 0.23 & $0.58 * * *$ & 0.23 & $0.51 *$ & 0.26 \\
\hline TOF & 0.31 & 0.24 & $-0.86 * *$ & 0.24 & $0.57 * *$ & 0.25 & -0.33 & 0.25 \\
\hline MAHCON & 0.03 & 0.09 & 0.03 & 0.09 & -0.16 & 0.09 & 0.01 & 0.09 \\
\hline \multicolumn{2}{|c|}{ Predicted Probability } & 0.45 & & 0.44 & & 0.45 & & 0.43 \\
\hline \multicolumn{2}{|c|}{ Joint probability(success) } & & & 0.03 & & & & \\
\hline \multicolumn{2}{|c|}{ Joint probability(failure) } & & & 0.08 & & & & \\
\hline \multicolumn{2}{|c|}{ Number of draws (\#) } & & & 5 & & & & \\
\hline \multicolumn{2}{|c|}{ Number of observation } & & 142.00 & & & & & \\
\hline \multicolumn{2}{|l|}{ Log likelihood } & & -304.29 & & & & & \\
\hline \multicolumn{2}{|l|}{ Wald chi2(56) } & & 183.34 & & & & & \\
\hline \multicolumn{2}{|l|}{ Prob $>$ chi 2} & & 0.0000 & & & & & \\
\hline
\end{tabular}

Estimated correlation mat

\begin{tabular}{lllll} 
& $\rho_{1}$ & $\rho_{2}$ & $\rho_{3}$ & $\rho_{4}$ \\
$\rho_{1}$ & 1 & & & \\
$\rho_{2}$ & $-0.424 * * *(0.126)$ & 1 & 1 & \\
$\rho_{3}$ & $-0.660 * * *(0.106)$ & $-0.107(0.141)$ & 1 & 1 \\
$\rho_{4}$ & $-0.067(0.139)$ & $0.236^{* *}(0.131)$ & $0.017(0.158)$ & 1 \\
\hline
\end{tabular}

Likelihood ratio test of: $\rho_{21}=\rho_{31}=\rho_{41}=\rho_{32}=\rho_{42}=\rho_{43}=0$

$\chi^{2}(6)=33.3643 \quad$ Prob $>\chi^{2}=0.0000 * * *$

Note: $* * *, * * *$ significant at $1 \%, 5 \%$, and $10 \%$, respectively. RSE is Robust standard error, $\rho_{1}=$ cooperative, $\rho_{2}=$ collectors, $\rho_{3}=$ retailers and $\rho_{4}=$ consumers

Source: Model result, 2019

Land size allocated for grazing (GLHS): The likelihood of choosing cooperative and retailers market outlet was positively relate to the size of land allocated for grazing both at $10 \%$ levels of significance. The result indicated that those households who allocated a large size of land for pasture would produce more output and then likely to sell to cooperative and retailer outlets. The result is consistent with the findings of Tadele (2012) who found that owning large land size is suitable for milk production in large quantity and supply to an alternative market that demanded higher quantity with relatively better price.

Membership to a dairy cooperative: The primary dairy cooperative membership influenced the likelihood of choosing cooperative market outlet positively and significantly at $1 \%$ significance level. The reason behind this is that the farmers who collectively market their produce to markets tend to incur lower transaction costs. This finding is in line with the (Sharma 2016), who stated that the membership is positively related to market choice, that means if a farmer is a member of farmers' group/ association/cooperatives, he/she is likely to participate in modern markets, besides reducing transaction costs, collective marketing empowers farmers to negotiate better trade terms and prices.

A number of milking cows owned (NMCO): As expected, the result shows that the number of milking cow increase the likelihood of choosing collectors' outlet at 1\% significance level. An increase in the number of milking cow increasing the likelihood of choosing more market outlet. This is because the number of milking cow can directly increase the marketable supply of milk and as milk production increase, farmers' capability to supply increase to more than one channels milk sell outlet. This is in line with the finding of Jaiswal et al. (2016) that stated as the number of milk animals' increases, the probability to sell milk to market channel increases all other factors held constant. 
Of farm/Nonfarm income household (OFFARM): As expected, Access to off/non-farm income has a positively significant on the probability of farmers to sell their product to retail outlet at $10 \%$ significance level. Farmers who have access to off/non-farm income have more possibility to choose retailer outlet compared to those who have no access to off/non-farm income. Income from off/non-farm income generating activities the enables farmers to purchase different inputs required to produce more milk. Income from off/non-farm strengthens the financial capacity of farmers to improve the production process and enable them to choose an appropriate market channel. Farmers prefer Retailer and consumers, which may far from them and pay a fair price to sell milk. Hence, producers sell the product to the retailer market outlet rather they might supply for other market outlets. This result disagrees with the finding of Zebrhe (2017) that non-farm income negatively affected selling milk to more outlet.

Frequency of extension contact (FEC): Number of extension contact has negative and significant relation with collectors' market outlet at 5\% significant level. However, extension contact frequency positive and significant influence with retailer and consumers outlet choice decision at $1 \%$ and $10 \%$ significance level, respectively. Households who were visited more by extension agent were more likely to deliver milk via retailer and consumers outlets than households less visited by extension agent. Extension contact enables the farmer to improve production means hence leading to more productivity, which in turn more likely to sell milk through retailer and consumers market outlets. This result is in line with the result obtained by Berhanu et al. (2013) who found access to dairy extension services positively and significantly affected accessing hotel/restaurant milk market outlet as compared with accessing individual consumer milk market outlet.

Transport ownership facilities (TOF): Access to transport ownership facilities influenced the choice of rural collector's outlet negatively and significantly at 5\% significant level while transport ownership facilities positively and significantly affect retailer at $5 \%$ significant level. Transport ownership facilities by farmers increased the likelihood of choosing another market outlet, which might far market outlets. This might be due to the reason that farmers who have access to the facility could supply their product to urban and sale to retailer or consumer directly by getting a better price that might go to the rural collectors. This shows that the availability of transportation facilities helps to reduce long market distance constraints, offering greater depth in marketing choices. This result is in line with that of Nuri (2016) who found that owning transport facilities influenced the choice of the wholesale outlet positively and significantly.

\section{Recommendations}

Based on the results of this study, the following policy implications are recommended so as to be considered in the future intervention strategies which are aimed at the promotion of dairy production and value chain analysis of milk in the study area in particular.

The result of multivariate probit model analysis shown that collectors channel choice is negatively and significantly influenced by the sex of sampled household as compared to retailer channels choice that affects positively and significantly. This implies that female head household mostly does not participate in far distance market. Therefore, it will be good if policies strengthen the support being given to the female-headed households using different methods like by increasing their awareness through affirmative actions, increasing their participation in different institutions support them on engaging in market participation.

The likelihood of accessing cooperative milk market outlet was positively and significantly influenced by dairy farming experience outlets and membership to a dairy cooperative market outlet. Therefore, farmers should have organized in cooperative and the government should create awareness on the importance of cooperative in order to get financial and technical capability and can solve the problem of searching to their product market sales for fair price outlet. In addition, strengthening the existing farmers' dairy cooperative and establishment of new organizations such as local cooperatives and collective groups supports farmer-to-farmer experience sharing.

The likelihood of accessing retailers and consumers' market outlet were significantly and positively influenced by frequency extension contact as compared to accessing collectors' market outlets that affect significantly and negatively. This implies as farmers access to frequency of extension contact increase, the aptitude to choice good market outlet for the product in terms gaining fair price also increases. Extension services in agriculture are essential and it offers more than just expert assistance in the improvement of production and marketing, it also enables a flow of information and transfer of knowledge and scientific findings to practice that will help farmers in market channel choice. Therefore, strengthening dairy farming extension services should be considered as an important input for producing milk market outlet choice.

\section{ACKNOWLEDGMENTS}

This is part of my M.Sc study and I would like to extend my deepest thanks to Ambo University. It is a great pleasure to extend my appreciation to my employer, Adebba district cooperative union, for giving me chance to pursue my post graduate study. Many thanks are extended to the local administrations and communities in the study areas for their enthusiasm in sharing knowledge and experiences with regards to milk market. 


\section{REFERENCES}

Anandajayasekeram, P. \& Gebremedhin, B. (2009). Integrating innovation systems perspective and value chain analysis in agricultural research for development. Implications and challenges,ILRI (aka ILCA and ILRAD), $16,32$.

Azage, T., Berhanu, G., Dirk, H., Berhanu, H., \& Yoseph, M. (2013). Smallholder dairy production and marketing systems in Ethiopia. Improving Productivity and Market Success of Ethiopian Farmers Project (IPMS). International Livestock Research Institute (ILRI), Addis Ababa, Ethiopia

Belderbos, R., Carree, M., Diederen, B., Lokshin, B., \& Veugelers, R. (2004). Heterogeneity in R\&D cooperation strategies. International journal of industrial organization, 22(9), 1237-1263.

Berhanu, K., Derek, B., Kindie, G., \& Belay, K. (2013). Factors affecting milk market outlet choices in Wolaita zone, Ethiopia. African Journal of Agricultural Marketing, 1(2), 024-031.

Cappellari, L. and Jenkins, S.P. (2003). Multivariate probit regression using simulated maximum likelihood. The Stata Journal, 3(3), 278-294.

CSA (Central Statistical Agency), (2018). Key Findings of the 2017/2018 (2010 E.C) Agricultural Sample Surveys, Addis Ababa 2018.

Getachew, M. (2015). Value Chain Analysis of Cow Milk: The Case of Laelay Maichew Woreda, Central Zone of Tigray, Ethiopia. (MSc Thesis presented to the School of Graduate Studies, Aksum University).

Gezu, T., \& Zelalem, Y. (2018). Dairy Trade in Ethiopia: Current Scenario and Way Forward-Review. Journal of Dairy \& Veterinary Sciences, 8(1), 1-13.

Jaiswal, P., Singh, K.R., Ghule, A.K., \& Vishnoi, S. (2016). Marketed surplus and factors affecting milk market outlet choices in Raipur district of Chhattisgarh. Journal of Animal Research, 6(2), 139-145

Kadigi, M.L. (2013). Factors influencing choice of milk outlets among smallholder dairy farmers in Iringa municipality and Tanga city (Doctoral dissertation, Sokoine University).

KDANRM (Kofele District Agriculture and Natural resource management Office), (2019). Socio economic profile of Kofele District.

KDLFDO (Kofele District livestock and fishery development Office), (2019). Socio economic profile of Kofele District.

Mugerewa, B., \& Ture, M. (2009). Milk yield and reproductive performance of dairy cattle under smallholder management system in north-eastern Amhara region of Ethiopia. Tropical animal health and production, 41(7), 1597

Nuri, L. (2016). Value chain analysis of enset (ensete ventricosum) in Hadiya zone, Southern Ethiopia (Doctoral dissertation, Haramaya University).

Tadele, M., Tewodros, T., \& Noreen, B. (2014). Factors influencing urban and periurban dairy producers' participation in milk value addition and volume of milk value added in Welmera Woreda, West Shewa Zone of Oromia Regional State, Ethiopia. International journal of livestock production, 5(9), 165-172.

Tarekegn, K., Haji, J., \& Tegegne, B. (2017). Determinants of honey producer market outlet choice in Chena district, Southern Ethiopia: a multivariate probit regression analysis. Journal of Agricultural and Food Economics, Vol.5 (1), 20.

Wytze, B., Dawit, M., Binyam, K., Mahlet, Y. \& Jan van der, L. (2013). The Major Ethiopian Milksheds;an assessment of development potential (No. 735). Wageningen UR Livestock Research.

Yamane, T. (1967). Statistics, an introductory analysis, 2nd Edition. New York: Harper and Row.

Yitaye, A., Maria, W., Azage, T., \& Werner, W. (2007). Urban and peri-urban farming systems and utilization of the natural resources in the North Ethiopian Highlands. In Conference on International Agricultural Research for Development, Tropentag, pp 1-6

Zebrhe, T. (2017). Analysis of urban and peri-urban dairy marketing: The case of southern zone of Tigray region, Ethiopia (MSc Thesis presented to the School of Graduate Studies, Haramaya University).

Zegeyesh, T. (2016). Determinants of milk market supply and marketing channel choices: the case of soddo zuria district, wolaita zone of southern Ethiopia. (MSc Thesis presented to the School of Graduate Studies, Haramaya University).

Zelalem, Y., Emannuelle, G., \& Ameha, S. (2011). A Review of the Ethiopian dairy Sector: Ed. Rudolf Fombad, Food and Agriculture Organization of the United Nations, Sub Regional Office for Eastern Africa (FAO/SFE), Addis Ababa, Ethiopia. 